\title{
The Effect of Science, Environment, Technology, and Society (SETS) Learning Model on Students' Motivation and Learning Outcomes in Biology
}

\author{
Sukarman Hadi Jaya Putra \\ Universitas Nusa Nipa \\ sukarmanputra88@gmail.com
}

\begin{abstract}
The study aims to know the effect of the Science, Environment, Technology, and Society (SETS) learning model on students' motivation and learning outcome on the concept of environmental change and conservation. The method used in this study is quasi-experimental with a non-equivalent control design. The sample is the tenth grade of $M L A 3$ and MLA 1 respectively as experiment and control group, chosen by purposive sampling technique. The instrument in this study was a questionnaire to measure motivation and a multiple-choice test to measure student learning outcomes. The data were analyzed using a t-test. The analysis results show an effect of the SETS learning model on students' motivation and learning outcomes in biology on the concept of environmental change and conservation in the tenth grade of St. John Paul II Catholic Senior High School Maumere.
\end{abstract}

Keywords: Learning Outcome, Students' Motivation, SETS Learning Model

\section{INTRODUCTION}

One of the processes supporting education is learning (Dimyati \& Mudijono, 2015). Success in learning activities requires high learning motivation to encourage students to carry out the learning process. Learning is an activity carried out by the teacher under certain conditions so that the cognitive, affective, and psychomotor aspects of students change for the better (Hamalik, 2015). Learning aims to help students gain various experiences (Afandi, Chamalah, \& Wardani, 2013). Based on this experience, student behavior includes these three aspects and values or norms that function as controllers of student attitudes and behavior increases.

Based on the results of observations and interviews conducted at St. Catholic High School John Paul II Maumere, there are various problems in learning Biology. Some students are less active in learning activities, and student motivation is still low, so students pay less attention to the teacher's explanation and are less active in completing the tasks given so that student learning outcomes are still low. Rachmawati \& Rohaeti (2018) stated that more meaningful learning and touching students' lives were needed to increase students' motivation and learning outcomes.

Learning outcomes are several experiences students obtain covering the cognitive, affective, and psychomotor domains (Sudjana, 2014). The success achieved in learning is seen from the final results achieved by students and many factors that influence it. These factors exist and occur during the learning process, one of which is the motivational factor possessed by students in participating in the learning process (Suprihatin, 2015). Uno (2016) stated that motivation is a force, both from within and from outside, that drives a person to achieve specific predetermined goals. Motivation is a factor driving the success of learning well. Without high motivation, the learning process will be 
hampered so that students are not serious about participating in learning (Widoyoko, 2018). Student motivation is very influential on student learning outcomes. With motivation in learning, students become enthusiastic and motivated to take learning seriously. In the learning process in the classroom, the teacher must generate learning motivation in students to actively take part and be involved in the teaching and learning process in the classroom (Yusuf, 2018).

Communication or interactions between teachers and students in the classroom also determine the learning outcomes that students will achieve. During the teaching and learning process, it is hoped that active communication will occur, meaning that it involves two parties, namely the teacher and students, so that the learning process does not seem monotonous and can be fun. Hamdu \& Agustina (2011) stated that if students' learning motivation is high, learning outcomes will be high. Otherwise, if students' motivation is low, learning outcomes will also low. A student's learning activities will be successful if they have high motivation.

One of the efforts that teachers can make to improve learning to be more effective is through the Science, Environment, Technology, and Society (SETS) learning model (Binadja, 2002). Several previous studies that have successfully used SETS in increasing student motivation and learning include. Nugraheni, Mulyani, \& Ariani (2013) explained a significant effect of learning with vision and SETS approach on the cognitive and affective learning achievement of tenth grade SMAN 2 Sukoharjo petroleum material. Yuniastuti (2015) also showed a significant influence between the SETS learning model on the Biology learning outcomes of the seventh semester II students of SMP Kartika V-1 Balikpapan on the pollution material. Aprianingtyas \& Sumadi (2016) stated a very significant difference in physics learning achievement on the subject of solid, liquid, and gas pressures for eighth-grade students in the even semester of SMP N 2 Ambal Kebumen between the SETS and conventional learning models. Although there is a significant effect, this study did not examine student learning motivation which is very influential in student learning outcomes.

Binadja (2002) stated that the central point of learning science with a SETS perspective is the amalgamation of the scientific concepts studied and their implications for the environment, technology, and society. Students are expected to have the ability to master concepts, increase creativity and awareness in understanding issues related to environmental conservation. Active student involvement in this learning strategy can help students solve real problems and respond actively to natural phenomena around students (Widiani, 2017). Through this model, students will be more active in participating in learning because students can learn by relating problems that occur in the environment to increase learning outcomes. In this study, SETS can be pursued in increasing student learning motivation to provide better student learning outcomes in Biology subjects so that the desired KKM is achieved.

Based on this description, the purpose of this study is to improve student learning outcomes and motivation in Biology subjects using the SETS learning model at St. Catholic High School. John Paul II Maumere.

\section{METHOD}

The type of research carried out is quasi-experimental research. The research design used is the Non-equivalent Control Group Design by using two classes, namely the experimental and control groups. The design in this study is shown in Table 1. 
Table 1. Non-Equivalent Control Group Design

\begin{tabular}{cccc}
\hline Group & Initial State & Treatment & Final State \\
\hline Experiment & $\mathrm{Q}_{1}$ & $\mathrm{X}$ & $\mathrm{Q}_{2}$ \\
\hline Control & $\mathrm{Q}_{3}$ & - & $\mathrm{Q}_{4}$ \\
\hline
\end{tabular}

Description:

$\mathrm{Q}_{1}=$ The results of the pretest learning outcomes of the experimental student group

$\mathrm{Q}_{2}=$ Posttest results of experimental student group learning outcomes

$\mathrm{Q}_{3}=$ The results of the pretest learning outcomes of the control student group

$\mathrm{Q}_{4}=$ The results of the post-test learning outcomes of the control student group

$\mathrm{X}=$ The experimental group treatment of students was treated with the SETS learning model

- $=$ Learning conditions are usually carried out by teachers or conventional learning

The research was conducted from 7 to 25 May 2020 at St. John Paul II Catholic High School Maumere, Alok District, Sikka Regency, East Nusa Tenggara, Indonesia. The population in this study were students of tents-grade, which consists of 6 classes. The samples in this study were students of tenth grade MIA 3 and MIA 1, respectively, as the experimental group (27 students) and control group (27 students). The sampling technique used in this research is purposive sampling. The determination of the sample can be seen from the ability to understand the material, where the value acquisition by some students does not reach the school standard. MIA 3 as an experimental group applying the SETS learning model, while MIA 1 as a control group applying a conventional learning model. The instruments used in the pretest and post-test questions were 19 items and 20 questionnaire items for student learning motivation. The test used is an objective test in the form of multiple choice. The instrument test results contained 19 valid questions and 11 invalid questions. The reliability test of the question is 0.94 , with a very high level of reliability. The difficulty level test has one easy question, 17 medium questions, and one difficult question, while the discriminatory power has six good questions and 13 excellent questions.

The motivation questionnaire used in this study consisted of 20 items. Each statement is provided with four alternative answers where students must choose one answer. The five alternative answers, including strongly disagree, disagree, unsure, agree, and strongly agree The determination consists of positive and negative items. The determination of motivation scores is presented in Table 2.

Table 2. Determination of Motivation Score

\begin{tabular}{ccc}
\hline \multirow{2}{*}{ Options } & \multicolumn{2}{c}{ Score } \\
\cline { 2 - 3 } & Statement Positive & Statement \\
\hline Strongly Disagree & 5 & 1 \\
\hline Disagree & 4 & 2 \\
Unsure & 3 & 3 \\
\hline Agree & 2 & 4 \\
\hline Strongly Agree & 1 & 5 \\
\hline
\end{tabular}

The categories of scores obtained by students can be seen in Table 3 . 
Table 3. Categories of Student Learning Motivation

\begin{tabular}{cc}
\hline Score & Categories \\
\hline$<1,8$ & Very low \\
\hline $1,8 \leq \mathrm{x}<2,6$ & Low \\
\hline $2,6 \leq \mathrm{x}<3,4$ & Currently \\
\hline $3,4 \leq \mathrm{x}<4,2$ & Very high \\
\hline $4,2 \leq \mathrm{x}<5$ & Very high \\
\hline
\end{tabular}

Data analysis techniques were carried out using normality test, homogeneity test, and hypothesis test. Hypothesis testing is done by statistical analysis of the t-test using the SPSS 21 program.

\section{FINDINGS}

Data on student motivation results were obtained using a questionnaire with 20 statement items. At the end of the learning activity, the researcher distributed learning questionnaires to students to determine students' motivation to learn biology in the experimental and control groups. The researcher motivates students by asking students about the subject matter by presenting environmental problems to explore students' curiosity and arouse students' enthusiasm for learning. Data on the results of student learning motivation can be seen in Figure 1.

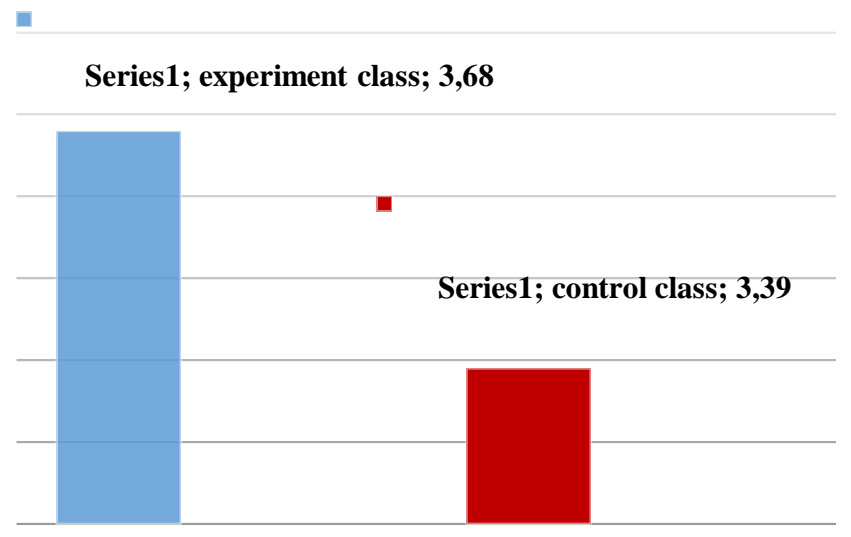

Figure 1. The Average Value of Motivation

Based on Figure 1, the average difference in student learning motivation obtained by the experimental group using the SETS learning model is 3.68 with a maximum score of 4.6 and a minimum score of 3.1, while the control group using the conventional model is 3.39 , with a maximum value of 3.75 and a minimum value of 2.7. This data shows that the experimental group students' learning motivation reached the high category compared to the control group reaching the medium category. Students with high motivation can be seen from the seriousness of these students in doing assignments and being active in discussion activities. Students with low motivation tend to feel bored and lazy during learning.

Before receiving the learning process using the SETS model, the student learning outcomes are presented in Figure 2. The pretest was given at the beginning of the learning activity before treating the experimental and control classes. Twenty-seven students took the pretest in the experimental group and 27 in the control group. The data from the students' pretest results can be seen in Figure 2. 


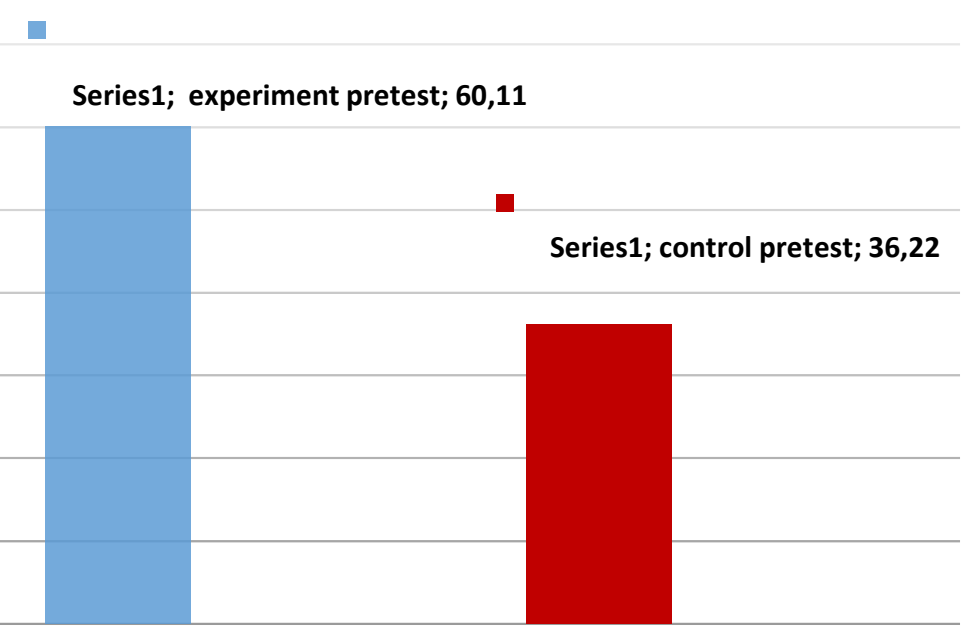

Figure 2. The Average of Pretest Learning Outcomes

Figure 2 shows that the difference in the average pretest obtained by the experimental group is 60.11 and the control group is 36.22. This data shows that the initial abilities of the experimental group and control group students are very different. The two classes were treated with two different learning models. Pretest was given at the beginning of learning in the control and experimental classes with 19 questions. Pretest results in the experimental group obtained a minimum value of 32, a maximum of 74 , and an average of 60.11 . The pretest results in the control group obtained a minimum value range of 21 , a maximum of 68 , and an average of 36.22 . This data shows that the average results of the pretest of the two classes are very different.

Other results can be seen in the standard deviation of the pretest in the experimental group of 10.040 while the control group is 11.178 . The standard deviation of the experimental pretest was greater than the standard deviation of the control group. This fact is because the pretest scores in the experimental group ranged from 32 to 74 . The range of pretest scores in the control group ranged from 21 to 68 . The size of the standard deviation shows that the level of understanding of the students' material is still much different. The standard deviation of the experimental group and control group can be seen in table 4 .

Table 4. Hypothesis Testing Pretest Experiment and Control Class

\begin{tabular}{cccccc}
\hline Variable & Group & N & Mean & $\begin{array}{c}\text { Standard Deviation } \\
\text { Pretest Experiment and } \\
\text { Control Class }\end{array}$ & $\begin{array}{c}\text { Significant } \\
\text { Level }\end{array}$ \\
\cline { 1 - 4 } $\begin{array}{c}\text { Learning } \\
\text { outcomes }\end{array}$ & Experimental & 27 & 60,11 & 10,040 & 0,000 \\
\cline { 2 - 5 }
\end{tabular}

Before testing the hypothesis of the pretest data, normality and homogeneity tests were first carried out. The normality and homogeneity test results showed that the pretest data were normally distributed and homogeneous. Based on the hypothesis testing in Table 4, it can be concluded that there are differences in cognitive learning outcomes between the experimental group and the control group. It can be concluded that the average value of the two groups has not reached the Maximum Completeness Criteria (KKM) because the two classes have not received the SETS learning model treatment in the experimental group and the conventional model in the control group.

The student's post-test learning outcomes data can be seen in Figure 3. The post-test was given at the end of the lesson after treatment in the experimental and control groups. The average 
post-test score obtained in the experimental group was 86.63, with a maximum score of 95 and a minimum score of 74 . The average score obtained in the control group was 69.56, with a maximum score of 84 and a minimum score of 53 . Students who obtained the highest score can be seen from the readiness of students and always pay attention to the explanation from the teacher when following the lesson. Students who get the lowest scores tend to be negligent in attending lessons and feel relaxed doing assignments.

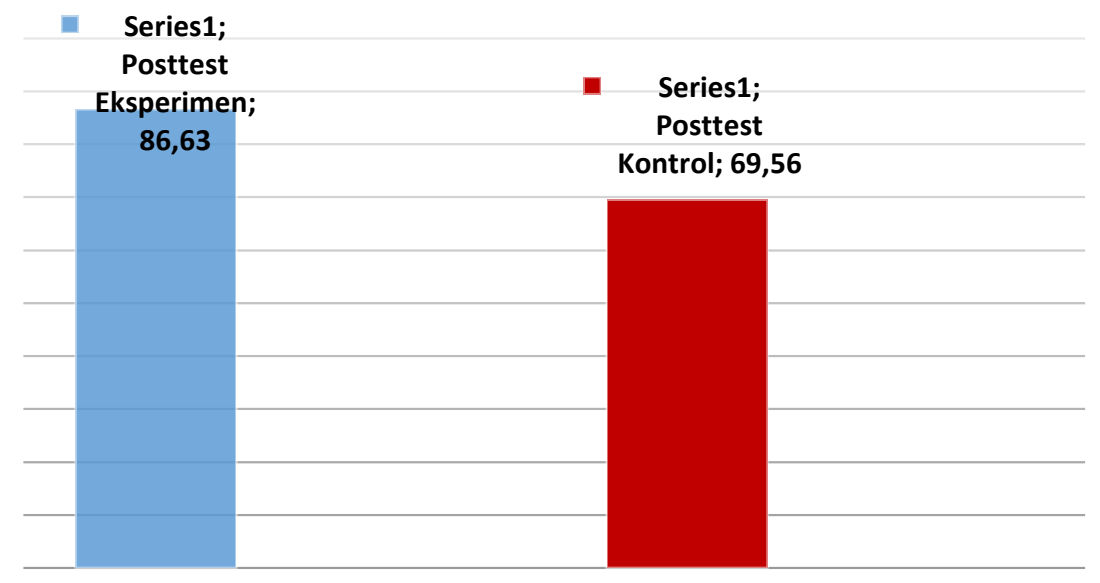

Figure 3. The Average of Posttest Learning Outcomes

Based on Figure 3, the average value of the experiment is higher than the control group after being given a different treatment because the SETS model is a learning model that relates environmental problems to the material obtained. Setiawan, Rahayu, \& Hikmawati (2015) stated that through the SETS learning model, students could relate the concepts of science, environment, technology, and the benefits of technology in everyday life. Students can more easily understand the concept of knowledge to more easily remember the lessons received (Situmorang, Muhibbuddin, \& Khairil, 2015).

Other results can be seen in the standard deviation of the post-test in the experimental group of 6.246 while the control group of 8.405. The standard deviation of the post-test experimental group is greater than the control group. This fact is because the range of post-test scores in the experimental group ranges from 74-95. The range of post-test scores for the control group ranged from 53 to 84 . The size of the standard deviation shows that the level of understanding of the students' material in both classes is good. The standard deviation of the experimental group and control group can be seen in table 5 .

Table 5. Hypothesis Testing Posttest Experiment and Control Class

\begin{tabular}{cccccc}
\hline Variable & Group & N & Mean & $\begin{array}{c}\text { Standard Deviation } \\
\text { Pretest Experiment and } \\
\text { Control Class }\end{array}$ & $\begin{array}{c}\text { Significant } \\
\text { Level }\end{array}$ \\
\cline { 1 - 5 } $\begin{array}{c}\text { Learning } \\
\text { outcomes }\end{array}$ & Experimental & 27 & 86,63 & 6,246 & 0,000 \\
\cline { 2 - 5 }
\end{tabular}

Based on these results, it can be concluded that the SETS learning model affects student learning outcomes. 


\section{DISCUSSION}

Science, Environment, Technology, and Society (SETS) learning model allows students to understand the interrelationships between science, environment, technology, and society (Binadja, 2002). Through this model, students will be more active in participating in the learning process, where students can learn by relating problems that occur in the environment so that students' learning motivation can increase (Sukmawati, Wibawa, \& Antara, 2018). Motivation is very influential on student learning outcomes. The learning process will be successful when students have motivation in learning (Rusman, 2012). Therefore, teachers need to foster student learning motivation (Hamdu \& Agustina, 2011). Tatan \& Sumiati (2010) states that motivation is a person's strength that can raise the level of willingness to carry out an activity. Willingness comes from within the individual itself and from outside the individual.

This finding is in line with the opinion of Sunhaji (2014), which states that learning using the SETS model can provide opportunities for students to find or relate the material discussed to students' problems. The benefits of studying certain materials will be felt by students so that students will be motivated to learn (Emda, 2017). Daud (2012) states that learning motivation is the overall driving force in students that gives rise to learning activities, ensures the continuity of learning activities, and provides direction to learning activities so that the goals desired by students can be achieved.

Student learning outcomes increase by giving the SETS model in teaching and learning activities in the classroom. An experimental group uses the SETS learning model on environmental change and preservation material. During the learning process at the first meeting and the second meeting, the students were very active in linking the material between the concepts of science, environment, technology, and society and presenting the results of the discussion. The knowledge received will make students understand in-depth so that it impacts learning outcomes (Hamiyah \& Jauhar, 2014). This statement is in line with the research results by Fatchan, Soekamto, \& Yuniarti (2014), which states that the SETS learning model can improve students' science problem-solving abilities.

In contrast to the control group uses a conventional model. During the learning process at meetings I and II, students participated less actively in learning activities while the teacher spoke more so that learning was more monotonous than previous. The control group of students only received material with lectures, occasional discussions, and students were less active in working on group assignments. This fact is in line with the opinion of Aprianingtyas \& Sumadi (2016), which states that the conventional model is a learning model that makes students accustomed to obtaining information from the teacher instead of seeking information independently. In other words, learning activities are only teacher-centered (Berutu \& Tambunan, 2018). This condition causes learning activities to be less effective. Students are less motivated and passive in learning so that the achievement of learning outcomes does not reach predetermined completeness (Putra, 2021).

\section{CONCLUSION}

This research shows an effect of the Science, Environment, Technology, and Society (SETS) learning model on students' motivation and learning outcomes in biology on the concept of environmental change and conservation in tenth-grade of St. John Paul II Catholic Senior High School Maumere. 


\section{REFERENCES}

Afandi, M., Chamalah, E., \& Wardani, O. P. (2013). Model dan Metode Pembelajaran di Sekolah. Semarang: Unissula Press.

Aprianingtyas, M. \& Sumadi. (2016). Pengaruh Model Pembelajaran SETS (Science,Environment, Technology, and Society) Terhadap Prestasi Belajar Fisika Pokok Bahasan Tekanan. Jurnal Ilmiah Pendidikan Fisika-Compton, 3(2), 1-8.

Berutu, M. H. A. \& Tambunan, M. I. H. (2018). Pengaruh Minat dan Kebiasaan Belajar Terhadap Hasil Belajar Biologi Siswa SMA Se-Kota Stabat. Jurnal Biolokus, 1(2), 109-115.

Binadja, A. (2002). Pemikiran dalam SETS. Semarang: Universitas Negeri semarang.

Daud, F. (2012). Pengaruh Kecerdasan Emosional (EQ) dan Motivasi Belajar terhadap Hasil Belajar Biologi Siswa SMA 3 Negeri Kota Palopo. Jumal Pendidikan dan Pembelajaran, 19(2), 243-255.

Dimyati, \& Mudijono. (2015). Belajar dan Pembelajaran. Jakarta: PT. Rineka Cipta.

Emda, A. (2017). Kedudukan Motivasi Belajar Siswa dalam Pembelajaran. Journal Lantanida, 5(2), 172-182.

Fatchan, A., Soekamto, H., \& Yuniarti. (2014). Pengaruh Model Pembelajaran Science, Environment, Technology, Society (SETS) Terhadap Kemampuan Berkomunikasi Secara Tertulis Berupa Penulisan Karya Ilmiah Bidang Geografi siswa SMA. Jurnal Pendidikan dan Pembebelajaran, 21(1), 33-40.

Hamalik, O. (2015). Kurikulum dan Pembelajaran. Jakarta: PT Bumi Aksara.

Hamdu, G. \& Agustina, L. (2011). Pengaruh Motivasi Belajar Siswa Terhadap Prestasi Belajar IPA di Sekolah Dasar. Jurnal Penelitian Pendidikan, 12(1), 90-96.

Hamiyah, N. \& Jauhar, M. (2014). Strategi Belajar Mengajar di Kelas. Jakarta: Prestasi Pustakaraya.

Nugraheni, D., Mulyani, S., \& Ariani, S. R. D. (2013). Pengaruh Pembelajaran Bervisi dan Berpendekatan SETS Terhadap Prestasi Belajar Ditinjau dari Kemampuan Berpikir Kritis Siswa Kelas X SMAN 2 Sukoharjo pada Materi Minyak Bumi Tahun Pelajaran 2011/2012. Jurnal Pendidikan Kimia, 2(3), 34-41.

Putra, S. (2021). Pendekatan Jelajah Alam Sekitar (JAS): Dampaknya terhadap Aktivitas dan Hasil Belajar Kognitif Siswa SMP. Journal of Natural Science and Integration, 4(2), 204-213.

Rachmawati, D. \& Rohaeti, E. (2018). Pengaruh Model Pembelajaran Sains, Teknologi, dan Masyarakat Terhadap Kemampuan Berpikir Kritis dan Motivasi Belajar Peserta Didik. Jurnal Pendidikan Matematika dan Sains, VI(1), 29-39.

Rusman. (2012). Belajar dan Pembelajaran Berbasis Komputer. Bandung: Alfabeta.

Setiawan, T., Rahayu, S., \& Hikmawati. (2015). Pengaruh Model Pembelajaran Science Technology and Society dengan Metode Diskusi Terhadap Hasil Belajar Fisika Siswa Kelas VIII SMPN 1 Labuapi Tahun Ajaran 2014/2015. Jurnal Pijar MIPA, X(1), 64-68. 
Situmorang, R. M., Muhibbuddin, \& Khairil. (2015). Penerapan Model Pembelajaran Problem Based Learning untuk Meningkatkan Hasil Belajar Siswa pada Materi Sistem Ekskresi Manusia. Jurnal EduBio Tropika, 3(2), 51-97.

Sudjana, N. (2014). Penilaian Hasil Proses Belajar Mengajar. Bandung: PT Remaja Rosdakarya.

Sukmawati, N. M. S., Wibawa, I. M. C., \& Antara, P. A. (2018). Pengaruh Model Pembelajaran Science Environment Technology Society Terhadap Hasil Belajar Ilmu Pengetahuan Alam. Jurnal Ilmiah Sekolah Dasar, 2(3), 329-337.

Sunhaji. (2014). Konsep Manajemen Kelas dan Implikasinya dalam Pembelajaran. Jurnal Kependidikan, 2(2), 30-46.

Suprihatin, S. (2015). Upaya Guru dalam Meningkatkan Motivasi Belajar Siswa. Jurnal Pendidikan Ekonomi UM Metro, 3(1), 73-82.

Tatan, Z. M. \& Sumiati, T. (2010). Pengaruh Penggunaan Media Belajar dan Minat Belajar Terhadap Hasil Belajar Matematika (Eksperimen pada Siswa Kelas XI IPA SMA Negeri 8 Kota Tangerang Selatan Tahun Pelajaran 2010/ 2011). Jurnal Formatif, 1(1), 70-81.

Uno, H. (2016). Teori Motivasi dan Pengukurannya. Jakarta: PT Bumi Aksara.

Widiani, N. S. (2017). Pengaruh Model Pembelajaran SETS Berbantuan Media Audio Visual Terhadap Kompetensi Pengetahuan IPA Siswa Kelas V. e-Journal PGSD Universitas Pendidikan Ganesha Mimbar PGSD, 5(2), 1-11.

Widoyoko, S. (2018). Penilaian Hasil Pembelajaran Di Sekolah. Yogyakarta: Pustaka Pelajar.

Yuniastuti, E. (2015). Pengaruh Model Pembelajaran Science, Environment, Technology and Society (SETS) Terhadap Hasil Belajar Biologi Siswa Kelas VII SMP Kartika V-1 Balikpapan Tahun Pelajaran 2015/2016. Jurnal Sains Terapan, 1(2), 72-77.

Yusuf, B. (2018). Konsep dan Indikator Pembelajaran Efektif. Jurnal Kajian Pembelajaran dan Keilmuan, 1(2), 13-20. 